\title{
THE AMBIDEXTROUS LEADERSHIP AND ITS IMPACT ON ORGANIZATIONAL PERFORMANCE IN THE JORDANIAN GOVERNMENT SCHOOLS FROM THE VIEWPOINT OF TEACHERS
}

\author{
Sahar saleh Abdel Rahman AlKhawaldeh \\ Email: salkwdalt85@gmail.com \\ Jerash post office, Postal code (26119)
}

\begin{abstract}
The current study aimed at identifying the skillful leadership behaviors and measuring their impact on organizational performance in Jordanian government schools from the teachers point of view, and to achieve the goals of the study the researcher followed the descriptive analytical approach, in terms of applying the study tool, which was represented in a questionnaire consisting of (30) paragraphs, On the sample, which amounted to (356) male and female teachers from government schools in the Directorate of Jerash Education, the study reached a number of results, the most important of which were: The degree of availability of ingenious leadership behaviors among administrative leaders in Jordanian educational institutions is high, and the degree of organizational performance indicators in educational institutions Jordanian women are also high, and there is a statistically significant effect of adept leadership behavior in Jordanian educational institutions on organizational performance from the point of view of male and female teachers in Jordanian government schools, and the study recommended a number of recommendations, the most important of which were: the need to educate administrators in various fields The Kingdom's governorates by adopting an ingenious leadership style in management, as it has positive benefits for the education process in Jordan.
\end{abstract}

KEYWORD: ambidextrous, performance, leadership, organizational

\section{INTRODUCTION}

Educational institutions constantly face large and accelerated environmental changes, which constitute a challenge to become dynamic and adapt to the unstable and heterogeneous context of the education environment. Therefore, it is necessary for educational institutions to constantly adapt to external threats and opportunities and to interact with innovations and structural alignment, as the researcher finds that educational institutions It needs to be characterized by ingenuity, the interest in which has emerged as one of the main directives of the excellence of educational institutions and which is the distinctive feature of contemporary educational institutions, and that increases the institution's ability to invest its current competencies with Exploration of new competencies primarily at one time.

Many researchers emphasize that brilliant leadership is not only an important precedent for innovation at the organizational level, but also has a significant impact on individuals 
working in educational institutions, it contributes to increasing their capabilities to explore and invest to be innovative, and brilliant leadership is one of the most predictors of innovation Teachers and their organizational development (Zacher et al. 2016). Since ingenious leadership encourages both exploration behaviors and optimal investment among employees, therefore the combination of high levels of both exploration behaviors and investing in employee capabilities must lead to a very innovative organizational performance (Rosing et al. 2011). The ambidextrous leadership theory also assumes that leaders engaging in exciting leadership behavior, i.e. opening and closing, fulfill the requirements of strategic thinking patterns due to the fact that they encourage the exploration of behaviors and investing the capabilities of teachers (Zacher and Rosing, 2015). According to the researcher's knowledge, this study is considered the first of its kind in the Hashemite Kingdom of Jordan, which is based on studying the impact of ambidextrous leadership on organizational performance in Jordanian government schools from the teachers 'point of view.

\section{The study Problem}

The accelerating environmental changes have imposed many pressures on educational institutions of all kinds, seeking to enhance competitiveness, self-development and sustainable professional development. And the environment of educational institutions in Jordan is not immune to that, which made such institutions live in a state of tension and the need to search for leadership theories that are able to adapt and identify with these pressures, as well as work to explore and generate ideas and invest them properly, and then promote and implement them, This is to be specifically reflected in the organizational performance of these educational institutions. From here emerges the main question in measuring the impact of adept leadership on organizational performance in Jordanian government schools from the teacher's point of view. Thus, the problem of the study is embodied in the following questions:

1. What is the extent of the availability of ambidextrous leadership behaviours among the administrative leaders in the Jordanian educational institutions?

2. Measuring the indicators of organizational performance in Jordanian educational institutions?

3. Is there an impact of ingenious leadership behaviour in Jordanian educational institutions on organizational performance from the teachers' point of view?

\section{Study limitations}

1. Time-domain: The researcher will distribute study tools during the school year (2019/2020) from the second semester.

2. Spatial domain: The researcher will apply the study tools in the government schools of the Jerash Education Directorate.

3. The human field: The study will be limited to male and female teachers in government schools of the Jerash Education Directorate. 
Vol.8, Issue 2, pp.63-73, February 2020

Published by ECRTD- UK

Print ISSN: ISSN 2054-6351

Online ISSN: ISSN 2054-636X

\section{Purpose of the study}

The main objective of the current study is to measure the impact of brilliant leadership on organizational performance in Jordanian government schools from the teacher's point of view, as a case study on public schools affiliated to the Jerash Education Directorate, and from it, the following objectives emerge:

1. Disclosure of the availability of ingenious (open and closed) leadership behaviours among administrative leaders in Jordanian government schools.

2. Disclosing the level of organizational performance indicators in Jordanian government schools, through the Balanced Performance Assessment Card.

3. Test the relationship between ingenious leadership behaviours in Jordanian government schools and organizational performance.

\section{Study model:}

Through the study problem and its objectives, the study model was constructed as in Figure 1 , in order to test the study hypotheses and measure each of the study variables.

Figure 1: Study model

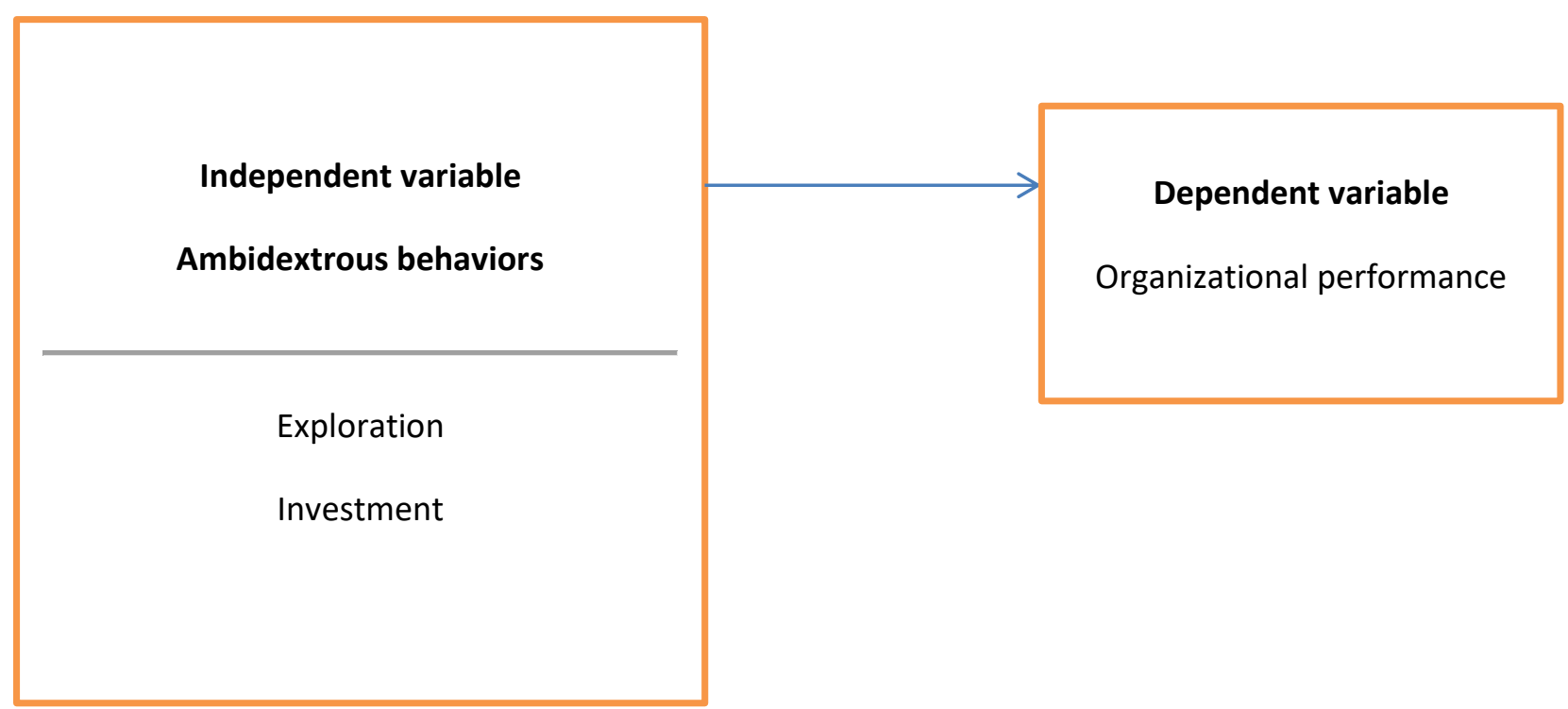

\section{The importance of studying:}

The importance of the current study is shown to be:

1. A modern concept of administrative leadership will be described in description and analysis, which is ingenious leadership, which has not received much attention from Arab researchers.

2. The current study will also attempt to explore the effect of subtle (open and closed) leadership on organizational performance indicators for department leaders in Jordanian government schools. 
British Journal of Education

Vol.8, Issue 2, pp.63-73, February 2020

Published by ECRTD- UK

Print ISSN: ISSN 2054-6351

Online ISSN: ISSN 2054-636X

3. The current study will also constitute a starting point in building and examining a contemporary management model consisting of consummate management behaviours as an independent variable and organizational performance as a dependent variable.

\section{Study assumptions:}

1. The organizational performance of educational institutions is related to the nature of the subtle managerial behaviours practised by leaders.

2. Ingenious management behaviours contribute to improving the organizational performance indicators for educational institutions.

Study population and sample:

The study community is represented by the teachers of public schools in the Jerash Education Directorate, who are (3119) male and female teachers, according to the last statistic for the year (2019), the sample will be randomly chosen from them, which will be according to the formula of Stephen Thompson (356) male and female teachers, which means $(11.4 \%)$ of Community size.

$$
n=\frac{N \times p(1-p)}{\left.\left[N-1 \times\left(d^{2} \div z^{2}\right)\right]+p(1-p)\right]}
$$

Whereas:

$\mathrm{N}$ : Community size

$\mathrm{Z}$ : the standard score corresponding to the significance level (0.95) and equal (1.96)

P: property, neutral and availability ratio $(0.50)$

$\mathrm{d}$ : error and equal ratio $(0.05)$

\section{Study tools}

The researcher will rely on the following tools to collect data and information:

1. Books, scientific sources, studies and research published in Arabic and English, related to independent and dependent study variables.

2. Developing a questionnaire to obtain the necessary data and information regarding ingenious leadership behaviours.

\section{The terminology of study}

1. Ingenious leadership: the ability to use the exploration and investment advantages to create a balance with the competitive environment and create distinctive capabilities in an organization, in other words employing exploration and investment to ensure short and long term success (Rosing and Bausch, 2011). 
2. Organizational performance: a broad concept that includes internal and external qualitative standards that reflect the organization's ability to achieve a wide range of goals towards multiple parties: workers, shareholders, customers, management and the local community (Maynard, 2006).

\section{Statistical methods:}

A number of statistical tests will be used to examine the study hypotheses as follows:

1. The Cronbach Alpha Factories for Determination of Reliability and Building Validity for Determination of Validity of Instruments.

2. Mathematical averages and standard deviations for estimating performance levels and subtle driving behaviours.

3. The simple correlation coefficient (person) through statistical programs (SPSS).

\section{THEORETICAL FRAMEWORK}

\section{First: ingenious leadership}

The most important characteristic of the environment of educational institutions is the complexity and contradiction whose effects on schools are reflected negatively or positively, in light of those schools to manage inconsistencies in a way that ensures them to keep pace with scientific developments and increase students 'motivation for learning and teachers to develop and advance professionally through sustainable professional development programs.

Studies related to the theory of contradiction indicate that there is no single leadership style that can be adapted to meet the requirements of the contradictory and complex environment, hence the need for leaders with sufficient behavioural and cognitive complexity that enables them to exercise multiple and varied roles simultaneously, and these ideas have emerged from the emergence of A new style of leadership presented under the title of brilliant leadership, the first model of which was developed by (Vera \& Crossan, 2004), and these researchers believe that the process of organizational learning needs a complex style of leadership, as this process can grow and develop under the misfortune of Transactional Leadership at times Specific, while we find It also grows exponentially in transformational leadership (Vera \& Crossan, 2004).

The ingenious leadership model is an attempt to get out of the oscillating state between these two types of behaviour. This new view of leadership comes in response to the pressures faced by educational institutions that practice both exploration and investment activities at the same time in order to deal with the different conditions resulting from the complexity and acceleration that characterized the environment. Contemporary educational institutions. Mom et al. (2007) views ambidextrous leadership as the ability of the leading individual to engage in exploratory and investment activities simultaneously, which is the ability to achieve a synchronized balance between learning contradictions to ensure the current and 
future success of the educational institution, as well as the ability to achieve synchronization in operations The paradoxical organizational learning of exploring new capabilities and expanding existing capabilities with equal skill.

Rosing et al. ( 2010) believes that leaders in the context of creativity need to be able to provide support to workers in their pursuit of ingenuity through ingenious leadership, and for this reason, they view ingenious leadership as representing a leader's ability to foster exploratory activities by adopting behaviour Open-mindedness and enhancing investment activities by adopting closed behaviour and flexible transition between the two types of behaviours according to the requirements of the situation. Seetge (2012) believes that brilliant leadership describes the ability of an individual to distribute his tasks, resources, and time between both exploration and investment activities with equal skill simultaneously for the purpose of overcoming the paradoxical tensions of learning and achieving success at work. The basic idea of ingenious leadership from the point of view (Zacher \& Rosing, 2015) is that the complexity of creativity activities must be matched by a complex leadership approach that is also complicated, and for this reason, the theory of creative leadership requires interaction between two complementary leadership behaviours that are open leadership and behaviours Closed leadership, and that this interaction is more effective in promoting creativity, whether at the level of individuals or at the level of teams compared to the style of single leadership, as is the case with transformational leadership or Transactional Leadership.

Seetge (2012) indicates that there is a need for different behaviours of leaders in order to foster creativity in the quality of exploratory and investment in an effective way, and for leaders to be able to practice different behaviours according to the requirements of the situation, they need two types of capabilities, the first being Behavioral Flexibility, and the second ability is Cognitive Complexity, the leaders who They have a high level of behavioural complexity and cognitive complexity, they can better understand the differences or changes that occur in the organization's environment and thus be able to manage the discrepancies between exploration and investment activities, and as a summary of the foregoing, ingenious leadership can be defined as Here the ability of the leader to employ

open behaviours and behaviours to promote investment closed and exploratory activities of the educational institution so as to enhance their efficiency and effectiveness in achieving the desired goals.

\section{Second: ambidextrous leadership behaviours}

It is clear from the previous presentation of the concept of ambidextrous leadership that it represents the leader's ability to reinforce the behaviours of exploration and investment activities for teachers, and in a more specific form, the approach to ambidextrous leadership includes two types of behaviour, the first is the open behaviour of the leader to enhance exploration activities and the second is closed behaviour to enhance investment activities. 


\section{Opening Leadership Behavior}

Opening Leadership Behavior defines a leader as a set of behaviours that includes encouraging to work and experimenting with different things, giving space for independent thinking and performance and providing support to challenge tiring methods and procedures, and among open leadership, behaviours is to stimulate thinking in a new direction to increase the difference in employee behaviour such as allowing mistakes and encouraging alternative means to accomplish Mission and pay the two actions to take risks (Coleman, 2016).

\section{Closing leadership Behaviors}

The behaviour of Closing leadership Behaviors is represented by a set of behaviours that include taking corrective actions, setting guidelines, and monitoring the achievement of goals, and the leader is expected to demonstrate this type of behaviour when the situation requires working individuals to ensure the implementation of the tasks assigned to them, which behaviours that focus on achieving efficiency and reducing Variations or differences in the behaviour of workers, such as adhering to the work protein, ensuring that laws are followed, monitoring the achievement of goals, and taking corrective actions whenever necessary (Rosing et al., 2011).

(Schindler, 2015) emphasizes that both open and closed leadership behaviours are related to each other in a way that is difficult to separate between them, for example, but not limited to achieving a goal is related to the leader's direction towards the goal and the perception of direction, and at the same time there is a need for a clear goal-setting and structure The task is to ensure that this goal is achieved, and it follows that both types of behaviour are interlinked to form an unprepared personal leadership style (Seetge, 2012).

\section{METHOD AND PROCEDURES}

The researcher used the descriptive-analytical method in answering the question of the study, as it suits the nature of the study.

\section{Study population and sample}

The current study community is composed of all (3119) teachers in the Jerash Education Directorate in the Hashemite Kingdom of Jordan for the academic year (2019/2020).

\section{The study sample}

The sample of the study was randomly chosen from the male and female teachers in the Jordanian government schools affiliated to the Jerash Education Directorate with (356) male and female teachers.

\section{Study tool}

The researcher has prepared a research tool consisting of (30) paragraphs divided into two axes. The first axis covered ingenious leadership (closed and open) behaviour by ten 
paragraphs for each behaviour, and the second axis covered organizational performance in Jordanian government schools by ten paragraphs as well.

\section{The Reliability of the study tool}

The researcher applied the tool to a survey sample from the study community by (20) male and female teachers twice with an interval of two weeks, to calculate the consistency of the study tool through the Alpha Cronbach equation which was (0.88) which is an appropriate value for this type of human studies.

\section{The Validity of the study tool}

The researcher presented the study tool to a number of teachers, school administrators and experts in statistics, who are (10) employees and experts in measurement to make sure that the paragraphs of the tool are appropriate and free of ambiguity and are valid for application, and after reviewing their views it was found that the tool is valid for application and with a compatibility rate of $(87 \%)$.

\section{Study procedures}

1. A review of theoretical literature and previous studies on the topic of ambidextrous leadership and organizational performance.

2. Development of the study tool in the way described previously

3. Determine the study sample individuals

4. Take the approved approvals to apply the study.

5. Distribute the questionnaire to the study sample and retrieve it.

6. Carrying out appropriate statistical analyzes, extracting and discussing results, and making recommendations.

\section{RESULTS}

To answer the first study's question: The researcher has derived the following criterion to determine the degree of availability of ingenious leadership behaviours among administrative leaders in Jordanian educational institutions from the point of view of male and female teachers as follows:

Table No. (1) comparison criterion

\begin{tabular}{lll}
\hline NO & Rang & Significance \\
\hline 1 & $\mathbf{1 - 2 . 3 2}$ & Low \\
2 & $\mathbf{2 . 3 3 - \mathbf { 3 . 6 5 }}$ & Average \\
3 & $\mathbf{3 . 6 6 - \mathbf { 5 }}$ & High \\
\hline
\end{tabular}

Then the researcher calculated the arithmetic mean of the degree of availability of ingenious leadership behaviours among the administrative leaders in the Jordanian educational institutions from the point of view of male and female teachers, which reached (4.25) with 
British Journal of Education

Vol.8, Issue 2, pp.63-73, February 2020

Published by ECRTD- UK

Print ISSN: ISSN 2054-6351

Online ISSN: ISSN 2054-636X

a standard deviation of (1.05), which is a high value based on the comparison criterion of the study.

To answer the second study question: Based on the previous criterion for measuring organizational performance indicators in Jordanian educational institutions from the point of view of male and female teachers?

The researcher calculated the arithmetic mean of the degree of availability of organizational performance indicators in Jordanian educational institutions from the point of view of male and female teachers, which reached (3.88) with a standard deviation of (0.98), which is a high value depending on the comparison criterion of the study.

To answer the third question of the study: Is there an impact of ingenious leadership behaviour in Jordanian educational institutions on organizational performance from the teachers' point of view?

The researcher used mono-contrast analysis to test the effect of ingenious leadership behaviour in Jordanian educational institutions on organizational performance from the viewpoint of male and female teachers, and the following table shows that:

Table No. (2) Analysis of mono-variance to test the effect of ingenious leadership behavior in Jordanian educational institutions on organizational performance from the viewpoint of male and female teachers.

\begin{tabular}{|l|l|l|l|l|l|}
\hline ANOVA & $\begin{array}{l}\text { Sum } \\
\text { Squares }\end{array}$ & of df & Mean Square & F & Sig. \\
\hline Between Groups & 50.027 & 2 & 25.01 & 23.60 & .000 \\
\hline Within Groups & 374.004 & 353 & 1.06 & & \\
\hline Total & 424.031 & 355 & & & \\
\hline
\end{tabular}

It is clear from the previous table that there is a statistically significant effect at the level of significance $(\alpha \geq 0.05)$ of ambidextrous leadership behaviour in Jordanian educational institutions on organizational performance from the point of view of male and female teachers, as the value of ( $\mathrm{sig}$ ) reached (0.000) which is less than the value of the level of significance ( $\alpha \geq 0.05$ ), thus rejecting the null hypothesis and accepting the alternative hypothesis.

The researcher attributes this result to the excellence of the masterful leadership of monkeys to strike a balance between the exploratory and investment skills that exist for male and female teachers, which would improve the educational process for school students and increase the ability of male and female teachers to be creative and progressive. 
British Journal of Education

Vol.8, Issue 2, pp.63-73, February 2020

Published by ECRTD- UK

Print ISSN: ISSN 2054-6351

Online ISSN: ISSN 2054-636X

\section{Recommendations}

1. Working on conducting this type of studies on a wider segment of male and female teachers in the Hashemite Kingdom of Jordan.

2. The results of this study are circulated by the Jordanian Ministry of Education to all departments affiliated to it.

3. Educating administrators in the various governorates of the Kingdom of the necessity of adopting an ingenious leadership style in management, because of its positive benefits to the education process in Jordan.

\section{REFERENCES}

Coleman, Nancy J. (2016). An Exploration of the Role of Leadership Behaviors and Ambidexterity in Online Learning Units. A Doctor of Education dissertation Submitted to The Faculty of The Graduate School of Education and Human Development of The George Washington University.

Maynard, Bill. (2006). Organization Performance Profile a Powerful newtool for transforming organization.www.EffectivenessInstitute.com.

Mom, T. J. M., Van den Bosch, F. A. J. and Volberda, H. W. (2007). Investigating managers' exploration and exploitation activities: The influence of top-down, bottom-up, and horizontal knowledge inflows. J. Management Stud. 44(6) 910-931.

Rosing, K, Frese, M, Bausch, A. (2011). Explaining the heterogeneity of the leadershipinnovation relationship: ambidextrous leadership.The Leadership Quarterly, 22(5), 956-974.

Rosing, K., Rosenbusch, N. and Frese, M. (2010). Ambidextrous leadership in the innovation process. In Innovation and international corporate growth. Springer Berlin Heidelberg, 191-204.

Rosing, K.; Frese, M.; Bausch, A. Explaining the Heterogeneity of the LeadershipInnovation Relationship: Ambidextrous Leadership. Leadersh. Q. 2011, 22, 956974. doi.org/10.1016/j.leaqua.2011.07.014.

Schindler, A. (2015). Ambidextrous Leadership: The role of flexibly switching between opening and closing leadership behaviors for team innovative outcome in the case of management consultancies. Master thesis of science in business administration. University of Twente.

Seetge, J. (2012). Leading innovation in fast-growing firms: A multiple case study in the Internet industry case study in the Internet industry. Master thesis of Science in Business Administration. University of Twente.

Vera, D. and Crossan, M. (2004). Strategic leadership and organizational learning. Academy of management review, 29(2), 222-240.

Zacher, H, \& Rosing, K. (2015). Ambidextrous leadership and team innovation. Leadership \& Organization Development Journal, 36(1), 54-68. 
British Journal of Education

Vol.8, Issue 2, pp.63-73, February 2020

Published by ECRTD- UK

Print ISSN: ISSN 2054-6351

Online ISSN: ISSN 2054-636X

Zacher, H, Robinson, AJ, Rosing, K. (2016). Ambidextrous leadership and Employees' selfreported innovative performance: the role of exploration and exploitation behaviors. The Journal of Creative Behavior, 50(1), 24-46. 